From the Department of Child Health and the Department of Clinical Pathology, Medical School, Airlangga University, Surabaya

\title{
Hemodialyis in a Child with Pyelonephritis and Nephrolithiasis
}

by

\author{
MOERSINTOWARTI B. NARENDRA, R.H. SARDJITO \\ DJOJOHADIPRINGGO and MARSETIO DONOSEPOETRO
}

\section{Introduction}

The principles of dialysis were first described by Abel, Rowntree and Turner in 1912 and are still applicable at present. Kolff in 1943 provided the first rotating drum dialyzer. According to Fine et al. (1968), hemodialysis has become acceptable as preparation of renal homotransplantation in chronic renal failure.

In 1963 Walker and associates reported a successful hemodialysis in a 7-month-old baby with nephrotic syndrome. Mauer et al. in 1973 reported a prolonged hemodialysis in a baby with a body weight of $4 \mathrm{~kg}$, starting at the neonatal period as a preparation of a subsequent successful renal transplantation.

Several events of hemodialysis among adults have been published in Indonesia; this report might be the first done in a child.
Case report

Swd., an 11-year-old Indonesian boy was admitted to the Pediatric Department of the Dr. Sutomo General Hospital, Surabaya, on April 30, 1973 , with the history of swelling of the face since three months, back pain, oliguria, pyuria, sometimes fever and cough.

He was the sixth child of a family with 8 children. On admission his body weight was $17,6 \mathrm{~kg}$, the temperature was $37^{\circ} \mathrm{C}$, the pulse rate was $100 /$ minute, and his blood pressure was $120 / 100$, the respiratory rate was 40 /minute; edema on his face was clearly present. Lungs and heart were normal, the liver and spleen were not palpable.

Urinalysis revealed albuminuria, many leucocytes, few erythrocytes per high power field, leucocyte casts and tubular epithelial cells. 
The supra pubic aspirated urine eulture revealed Paracolon bacilli of more than 100.000 per $\mathrm{mm}^{3}$ of urine. Blood analysis showed hemoglobine of $13 \mathrm{gm} \%$, WBC of 8200 per $\mathrm{mm}^{3}$, blood sedimentation rate $54-86$ within $1-2$ hours, BUN of $42,5 \mathrm{mg}$ per $100 \mathrm{ml}$, serum creatinine of 2,78 $\mathrm{mg}$ per $100 \mathrm{ml}$, a cholesterol level of $228,2 \mathrm{mg}$ per $100 \mathrm{ml}$, a total serum protein of $7,56 \mathrm{gm} \%$, albumin 3,13 $\mathrm{gm} \%$ and globuline $4,4 \mathrm{gm} \%$. The serum electrolytes were analysed for K $3,22 \mathrm{mEq} / \mathrm{L}$, Na $127,7 \mathrm{mEq} / \mathrm{L}$, $\mathrm{Cl}=100 \mathrm{mEq} / \mathrm{L}$.

The abdominal plain photo and intravenous pyelogram showed a nephrolithiasis duplex (fig. 1) ; both kidneys did not function at all and were of more than normal size. A small ureter stone on the right side and a $2 \times 1 \frac{1}{2} \mathrm{~cm}$ stone in the bladder were visible.

The patient was referred to the Surgical Department where he underwent surgery and was subsequently discharged on demand of the parents.

On July 21, 1973, the boy came again with the same complaints of oliguria, pyuria, sometimes lhematuria and abdominal pain. Two days before readmission he had nausea and vomiting. He looked very sick, pale and was soporic with episodes of excit- ement. Edema was absent but hematemesis occurred. The temperature was $38.5^{\circ} \mathrm{C}$, the pulse rate $104 / \mathrm{mi}-$ nute and the blood pressure was unmeasurable. Pus was present on the post operative wound which remained open. Blood examination showed a hemoglobine concentration of $\tau$ gm $\%$, a leucocyte count of 22.000 per $\mathrm{mm}^{3}$. Urinalysis could not be done due to anuria in the first 4 days of admission.

On admission infusion of glucose 10 $\%$ and Penicillin Procaine $600.000 \mathrm{U}$ were administered followed by blood transfusion on the next day. The blood pressure became normal, i.e. $110 / 80$, but the boy remained unconscious. The BUN was $115 \mathrm{mg}$ per $100 \mathrm{ml}$, the serum creartinine $16,7 \mathrm{mg}$. per $100 \mathrm{ml}$, the serum electrolytes were for $\mathrm{CO}_{2} 16,0 \mathrm{mM} / \mathrm{L}, \mathrm{Na} 83,3$ $\mathrm{mEq} / \mathrm{L}, \mathrm{K} 5,80 \mathrm{mEq} / \mathrm{L}$ and $\mathrm{Cl} 60$ $\mathrm{mEq} / \mathrm{L}$. The present diagnosis was. nephrolithrias's with pyeloneiphritis: resulting in renal failure. It was then decided to perform hemodialysis with the following method:

Shunting was done on the left saphenous vein and left superficial femoral arteria. Disposable Coil Kidney from Travenol Laboratory was used according to Kolff principles.

The dialysing fluid consisted of : 


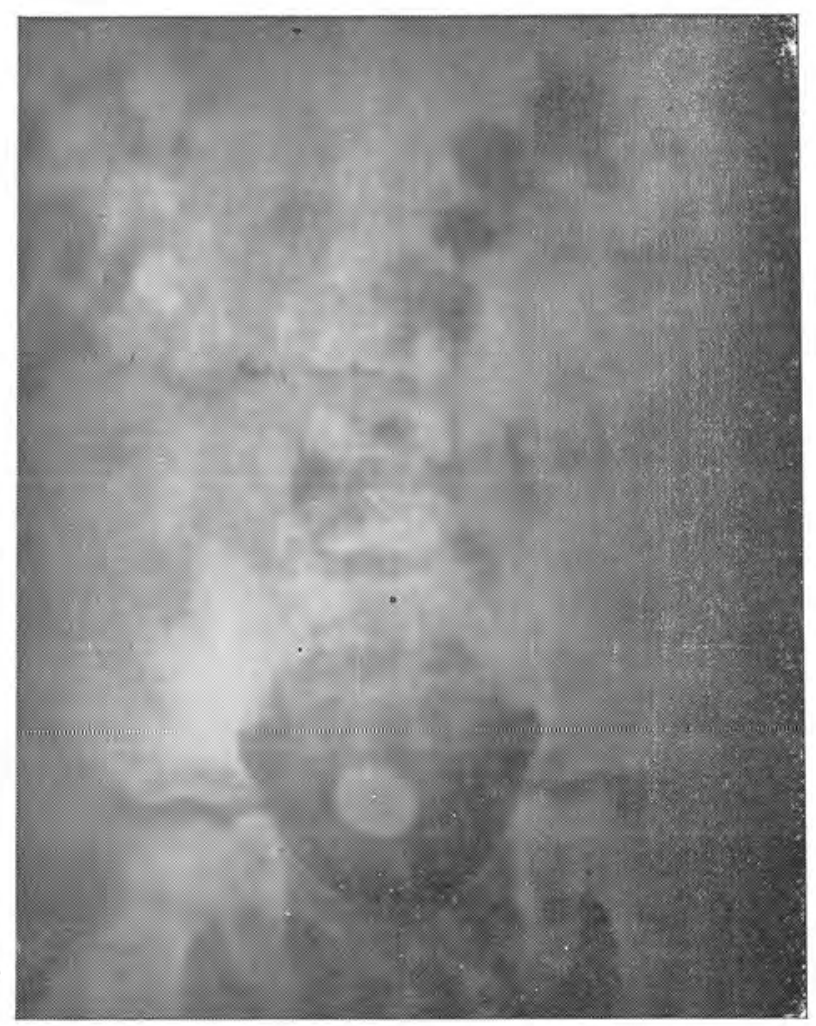

FIG. 1: Adbominal plain photo showed a Nephrolithiasis duplex in both kidneys, an ureter stone an the right and $a 2 \times 1 \frac{1}{2} \mathrm{~cm}$ stone in the urinary bladder. 


\begin{tabular}{|c|c|c|c|c|}
\hline Component & $/ 100 \mathrm{~L}$ & $\mathrm{Na}+\mathrm{K}+$ & $\mathrm{Mg}++\mathrm{Ca}++$ & $\mathrm{Cl} \quad \mathrm{HCO}_{2}$ \\
\hline $\mathrm{NaCl}$ & $570=$ & $97 \quad-$ & - & 97 \\
\hline $\mathrm{NaHCO}_{3}$ & $300=$ & $36 \quad-$ & - & 36 \\
\hline $\mathrm{KCl}$ & $30=$ & $-\quad 4$ & - $\quad-$ & - \\
\hline $\mathrm{CaCl}_{2}$ & $28=$ & $-\quad-$ & - 5 & - \\
\hline $\mathrm{MgCl}_{2}$ & $7,5=$ & $-\quad-$ & 1,5 & 1,5 \\
\hline Total & & 133 & 1,5 & 107,5 \\
\hline
\end{tabular}

B. Glucose of $400 \mathrm{mg} \%$ was added, and laotic acid was given to adjust the $\mathrm{pH}$ to approximately 7,4 .

To maintain the $\mathrm{pH}$ during dialysis, $90 \%$ of oxygen with $10 \%$ of $\mathrm{CO}_{2}$ was conducted through the fluid to bubbles.

The heparin used consisted of 10 $\mathrm{mg} / 100 \mathrm{ml}$ applied in the cannula, and 100 USP units per $\mathrm{kg}$ of body weight were given at the beginning of the hemodialysis.

For priming 3 units $(250 \mathrm{ml}$ per unit) of fresh blood in disposable plastic bags with a speed of $30-40 \mathrm{ml} /$ minute were administered.

The hemodialysis lasted 3 hours and 25 minutes (sce table 1 ).

TABEL 1: The recording during the hemodialysis

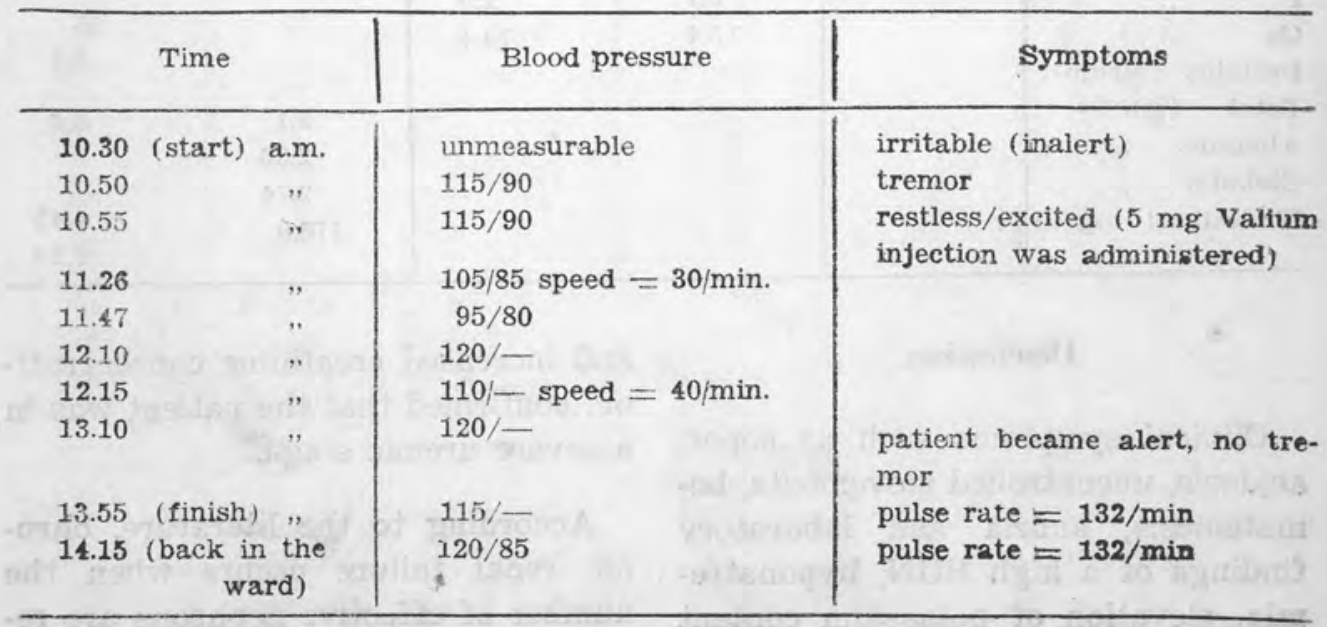


The next day after hemodialysis the patient's condition improved, he could chat with his mother; the blood pressure was $105 / 80$ but there was still oliguria (100 - $200 \mathrm{ml} / 24$ hours) and pyuria. $500 \mathrm{mg}$ Penbritin was administered intramuscularly, divided in 3 doses combined with Kantrex $15 \mathrm{mg}$ per $\mathrm{kg}$ body weight, dividied in 2 doses; these antibilotics were given since the day of hemodialysis for 7 conseculive days.

Two days after hemodialysis the cannula was removed. The hemoglo- bine concentration became $12 \mathrm{gm} \%$ and the child's condition improved considerably. However, on the sixth day after hemodialysis the general condition worsened: hematemesis, melaena occurred and the blood pressure went down to $100 / 70$. Blood transfusion was instituted to correct the anemia.

Four days later the boy fell in a coma, anuria became evidient, but a second hemodialysis was refused by the parents who took the boy home.

TABEL 2 : Laboratory data predialysis, during dialysis and postdialysis

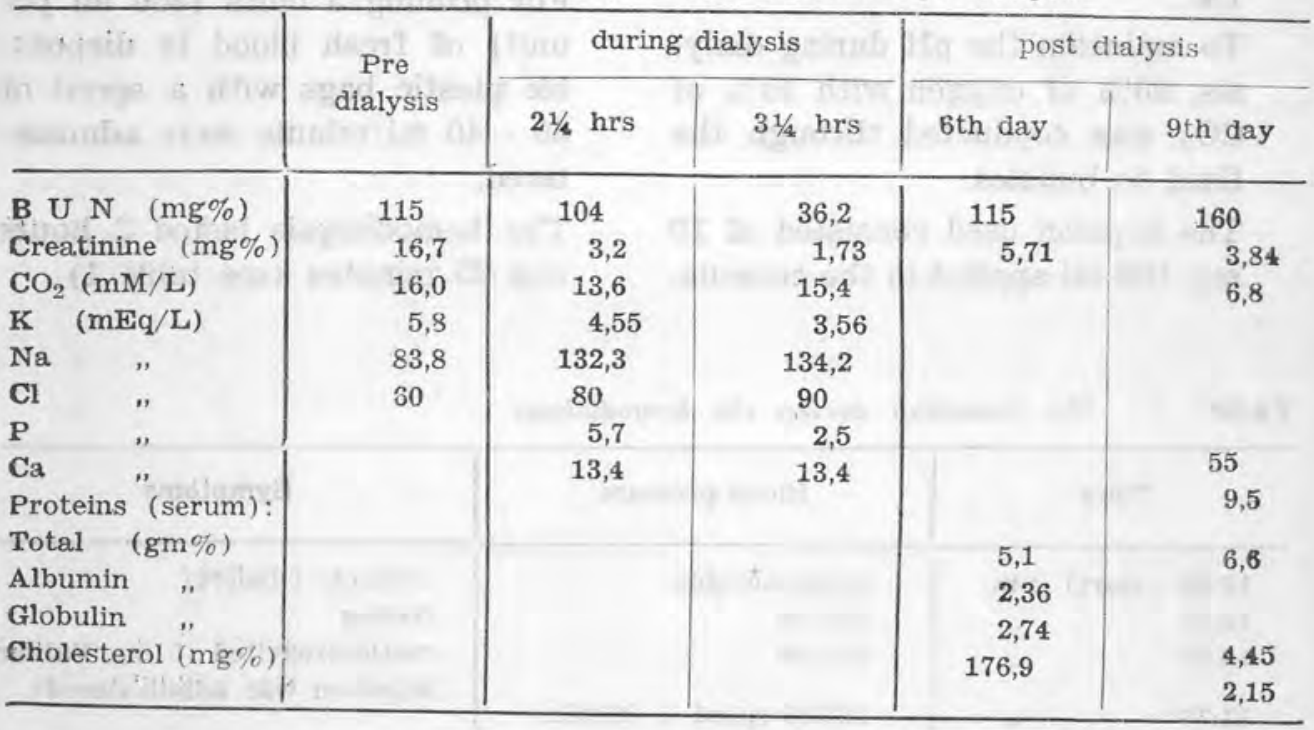

\section{Discussion}

Clinical symptoms such as sopor, acidosis, uncontrolled movements, hemartemesis, anuria and laboratory findings of a high BUN, hyponatremia, elevation of potassium content and increased creatinine concentration, confirmed that the patient was in a severe uremic stage.

According to the literature, chronic renal failure occurs when the number of effective nephrons are re- 


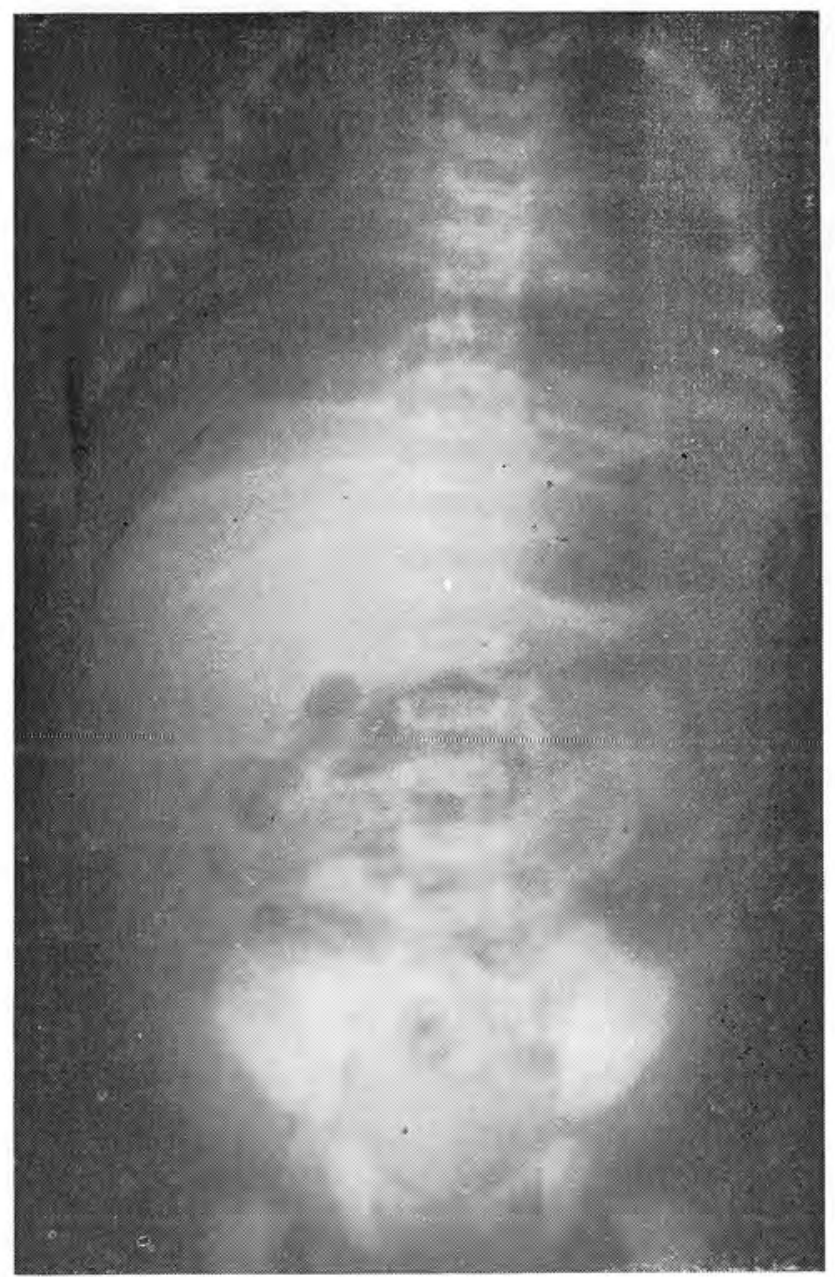

FIG. 1: X-photo of the abdomen (upright position) showed the presence of free air in the abdominal cavity. 


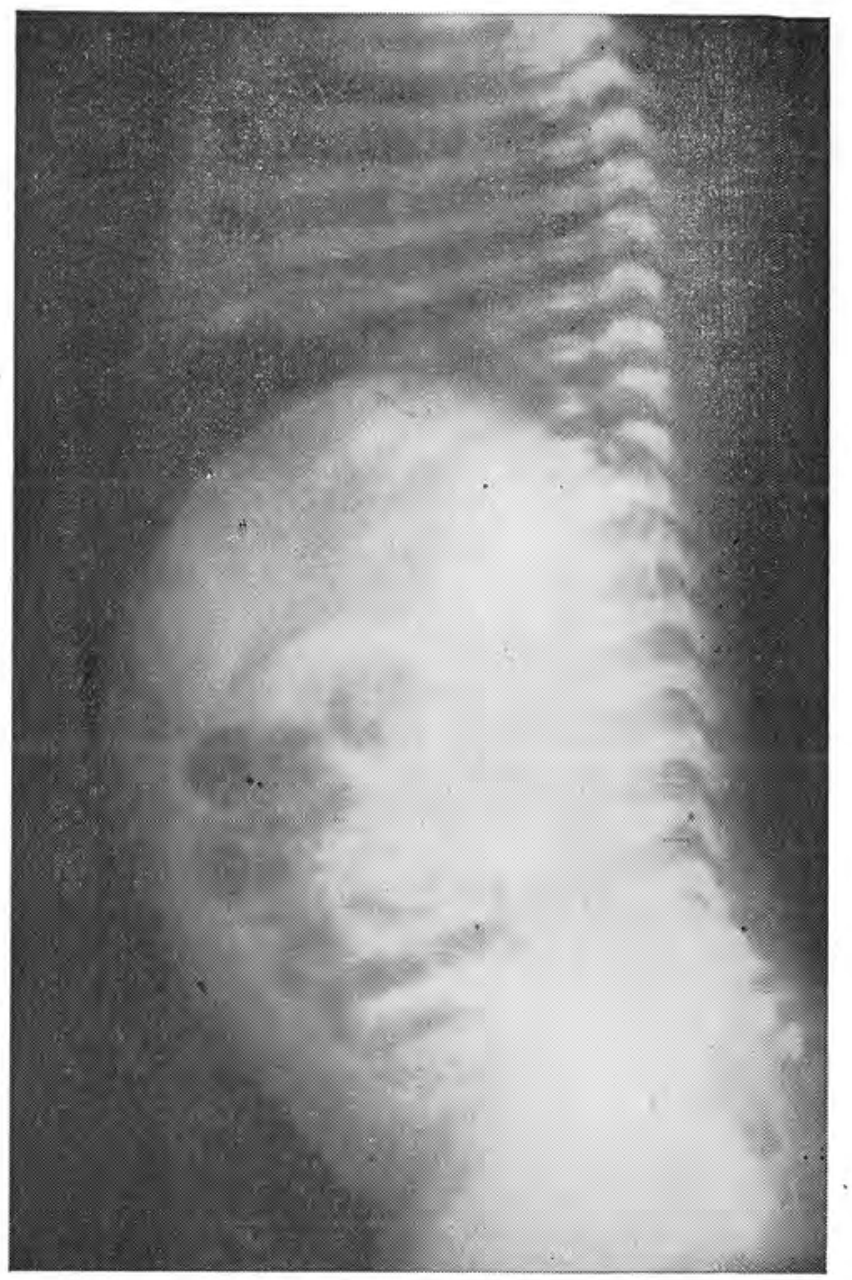

FIG. 2: $X$-photo of the abdomen (lateral decubitus position) showed the presence of free air in the abdominal cavity. 

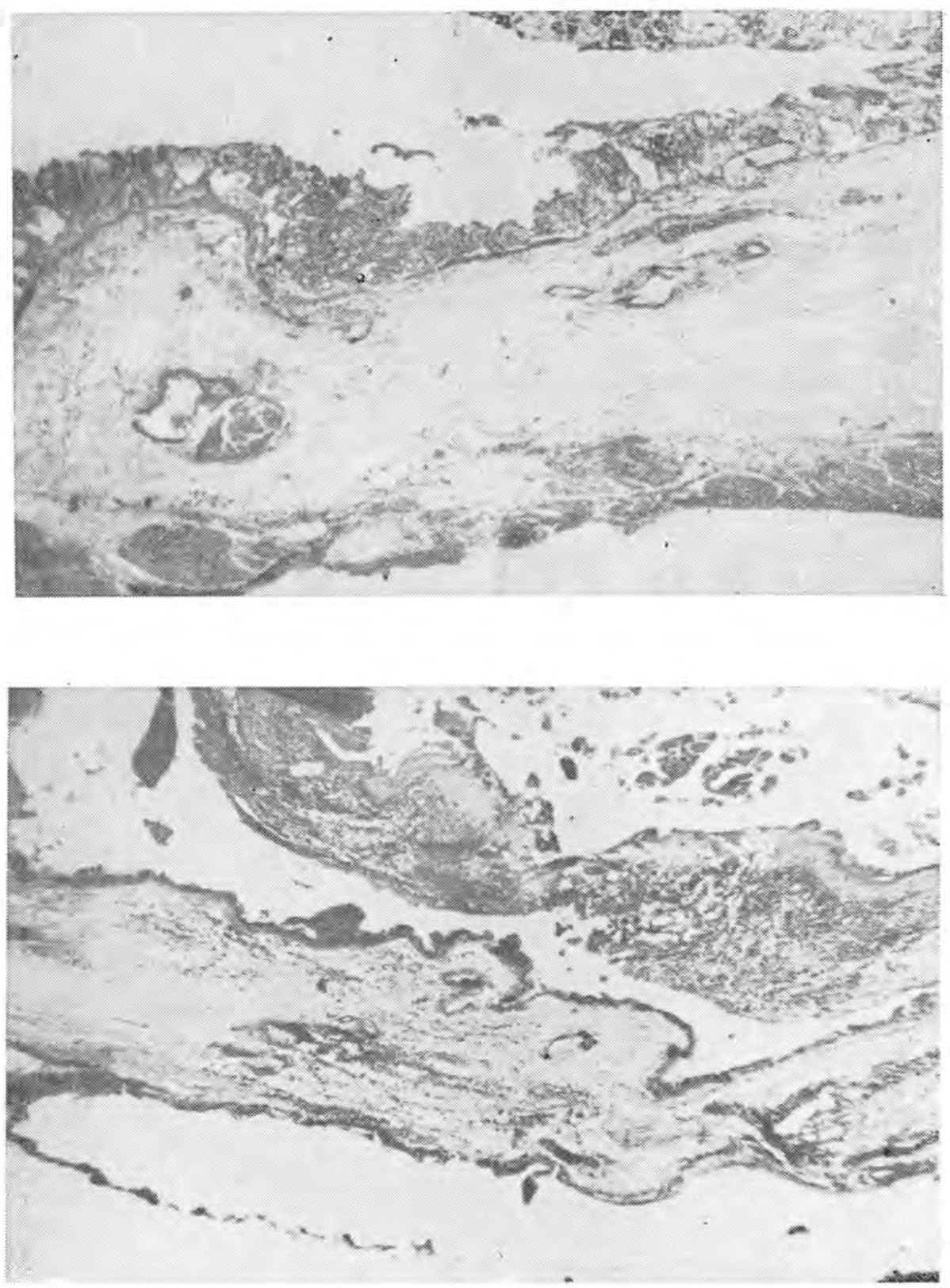

FIG. 3 \& 4 : P.A. No. 716398, $H$ \& $E$ stain, $X$ 35. Deficiency of malscularis of the stomach at the site of perforation. 
duced below the level required for normal function by the gradual progress of some disease process (Miller et al., 1966). In our case, recurrent pyelonephritis and chronic obstruction of the urinary tract by nephrolithiasis caused destruction of the majority of nephrons so that the remaining nephrons became hypertrophied in order to maintain the normal function. However, destruction progresses so that the final outcome ils a severe chronic renal failure.

Hemodialysis was indicated in our patient to obtain a better physical condition for the next step of operation (Kolff, 1960 and Potter, 1970). Regular hemodialysis is purely palliative and is most successful in those in whom renal failure is only slowly progressive, such as in chronic pyelonephritis (Miller et al., 1966). The difficult problem in our patient is how to overcome the overwhelming infection of the recurrent pyelonephritis.

Various authors reported that the most common difficulty in the procedure was the installation of the ca- theter through the small vessels of the children. Fine and associates (1970) suggested to use the radial artery and forearm vein in children with a body weight of more than 30 $\mathrm{kg}$, the brachial artery and cephalic vein in younger children of less than $30 \mathrm{~kg}$ of body weight and the superficial femoral artery and saphenous vein in infants (less than $10 \mathrm{~kg}$ ).

Minimal difficulties were encountered with the silicone rubber polytef arteriovenous cannula. We experienced the same difficulty in preparing cannulation in our patient but nevertheless the cannula could be maintained in its place for two days.

\section{Summary}

Hemodialysis as a first experience, done in an 11-year-old Indonesian boy with chronic uremia, pyelonephritis and nephrolithiasis has been reported.

\section{Acknowledgements}

We wish to thank the Surgical Departmenit, Medical School, Airlangga Unliversity for their cooperation.

\section{REFERENCES}

1. ABEL, J.J.; ROWNTREE, L.G. and TURNER, B.B.: The removal of diffusable substances from the circulating blood by means of Dialysis. Ass. Amer. Phycns. 28 : 51 (1913).

2. FINE, R.N.; KORSCH, B.M.; GRUSHKIN, C.M. and LIBERMAN, F.: He- modialysis in children, Amer. J. Dis. Child. 119 : 498 (1970).

3. FINE, R.N.; De PALMA, J.R.; LIEBERMAN, E.; DONNELL, G.N.; GORDON, A. and MAXWELL, M.H. : Extended Hemodialysis in childres with chronic renal failure. Pediat. 73 : 706 (1968). 
4. KOLEF, W.J.; BERK, J.T.J.; TERWELLE, M.; VAN DER LEY, A.J.W.;

1. VAN DIJK, E.C. and VAN NOOR-

110 DWIJK, J.: Een Dialysator met groot

14 appervlak. Geneesk. Gids. 21:40r (1943).

5. KOLFF, W.J.: Acute Renal Failure 1960, Postgrad. Med. 28 : 248 (1969).

6. MAUER, S.M.; SHIDEMAN, J.R.; BUSELMEIER, T.T. and KJELLSTRAND, C.M.: Long term hemodialysis in the neonatal period. Amer. J. Dis. Child. 125 : 269 (1973).

7. MILLER, A.; SLADE, N. and LEATHER, H.M.: Acute renal Failure in

\begin{abstract}
A synopsis of Renal Diseases and Urology. p. 45 (John Wright \& Sons, Bristol 1966).
\end{abstract}

8. POTTER, D.; LARSEN, D.; LEUMANN, E.; PERIN, D.; SIMMONS, J.; PIEL, C.F.and HOLLIDAY, M.A. : Treatment of chronic Uremia in Childhood II - Hemodialysis. Pediatrics $46: 678$ (1970).

9. WALKER, C.H.M.; WERSHING, J.M.; SIMON, S.I; HOLMES, T.H.; SITPRIJA, V. and O'BRIEN, D.: Hemodialysis in Infantile Nephrotic Syndrome. Amer. J. Dis. Child. 106 : 479 (1963). 